\title{
CARING FOR JUSTICE IN A NEOLIBERAL UNIVERSITY
}

\section{Hölscher}

\author{
School of Applied Human Sciences \\ University of KwaZulu Natal \\ Durban, South Africa \\ e-mail: holscher.dorothee@gmail.com
}

\section{ABSTRACT}

This article is based on a study on participatory parity in higher education in South Africa. Its purpose is to explore the nature of the relationship between care and social justice under conditions of neoliberalism. Using the lenses of Joan Tronto's democratic ethics of care and Nancy Fraser's work on social justice, I also reflect on my own practices as a social work lecturer in a university that has a high percentage of students who, by their own accounts, are poor. Based on the study's findings and my reflections thereupon, I argue that the context of higher education in South Africa renders relationships between students and lecturers vulnerable to replicating and reinforcing prevailing injustices in the sector. However, in the face of such entanglement, to care emerges as subversive practice, apt to substitute some of the key conditions and processes at the root of the injustices afflicting the field. I conclude that a democratic ethics of care can be employed to further the ends of social justice against the odds of a neoliberal learning context. This will also contribute to enhancing the well-being and academic development of both students and staff.

Keywords: Joan Tronto, Nancy Fraser, justice, care, social reproduction, neoliberalism, higher education, social work, South Africa

\section{INTRODUCTION}

Joan Tronto $(2014 \mathrm{a}, 22)$ asserted that, “care ... profoundly ... stands against one of the sharpest of the current masters' tools: neoliberalism". It is in this context that she called on those committed to a political, or democratic, ethic of care to explore further "the relationship of care to neoliberalism" (Tronto 2014b, 226) so as to establish in more detail what care requires under contemporary social, economic, and cultural conditions. This article is intended as a response to this call. Its purpose is to explore the nature of this relationship within a South African university, and the implications thereof for the teaching and learning practices in the discipline of social work. I will be arguing two main points. Firstly, on account of the neoliberal conditions under which it operates, the field of higher education in South Africa may be considered structurally unjust. This renders relationships between students and lecturers vulnerable to replicating and reinforcing, rather than providing a site of resistance to, the contextual injustices within which they are set. Secondly, I will argue that in the face of such entanglement, to care 
is a subversive practice, apt to substitute some of the key conditions and processes that lie at the root of contemporary injustices in South African higher education.

This article's arguments are rooted in my involvement in an NRF-funded study on higher education in South Africa (Bozalek 2014). The study was conducted in nine differently placed public universities and focused, among other things, on "students' experiences" of "participatory parity", and on how the use of "transformative pedagogical practices" might make it possible "for students to participate as equals" in South African higher education (Bozalek 2014, 6) ${ }^{1}$. My role entailed working, in August 2015, with a colleague and a group of 25 final year social work students. We conducted our leg of the study in an urban university that had been created in the early 2000s through the merger of an historically white and an historically black institution. Over a total of nine group sessions, students spoke, among other things, about factors that impacted their efforts to engage as equals with other students, lecturers, and the university administration. Their accounts prompted me to reflect on my own struggles in a context where I felt frequently unable to provide that care which students said they required. In this article, I am concerned with students' vis-à-vis my own experiences of voicelessness when it came to articulating our respective needs for care, as well as with the challenges surrounding my desires to build relationships of trust and solidarity with those whose education I was entrusted with.

In the following two sections I discuss a selection of ideas developed, over the past thirty years, by the political philosophers Joan Tronto and Nancy Fraser. The two authors are not often discussed in conjunction, yet both have chronicled, over three decades, a tightening grip of neoliberal capitalism on social reproduction generally and in such fields as education, health, and welfare more specifically. While Tronto has focused predominantly on the concept of care, much of Fraser's writing has centred on questions of justice. Both, however, have made great efforts to explore how, under the evolving contextual conditions in these fields, practitioners and academics might respond to protect, deepen and further the ends of both justice and care. At the end of Section III, I relate Tronto's and Fraser's thoughts to the South African higher education context, with specific reference to the context of the study reported here. Students' voices are presented and discussed in Section IV, alongside some reflections on my role, responsibilities, challenges, and responses to them. In the process, scarcity of money and time, and the deleterious effects thereof for relations of justice and care in the students' lives, can be shown to be particularly salient. I conclude that a democratic ethics of care can be employed to further the ends of social justice against the odds of a neoliberal learning context - particularly by helping to provide, protect and expand opportunities for various stakeholders to engage on a par. This would also contribute towards enhancing the well-being and academic development 
of both students and staff.

\section{JUSTICE AND CARE}

In 2014, Tronto bemoaned that many theorists continued to regard justice and care as separate spheres in which different forms of ethical reasoning applied. Yet according to Tronto (2014a), the relationship between justice and care had been explicated adequately in Moral Boundaries (Tronto 1993), which concluded with the assertion that,

"Care is a necessary, though not by itself a sufficient part of our account of moral life. To address and to correct ... [existing] problems with care ... requires a concept of justice, a democratic and open opportunity for discussion, and more equal access to power." (1993, 154; brackets added).

At the same time, Fraser (in Bozalek 2012,144) described the relationship between justice and care, and between her own and Tronto's reasoning, as follows:

"I see the question of how care is organised precisely to be a question of justice .... So I think Tronto and I have similar political intuitions about the kind of society that we want .... It is also true that I ... think in a more macro way. But I want to do macro theory in a way that leaves room for and takes account of ... particularity." (Brackets added).

Beyond these broad claims, how are the two concepts - care (as espoused by Tronto) and justice (as espoused by Fraser) - connected? Can they, together, provide for a fruitful framing of the concerns at the heart of this article? Tronto (1993) referred to care as both a standard against which to assess "how well or how badly care is accomplished in any given society" and $a$ practice that "puts moral ideals into action" in that "by focusing on care, we focus on the processes by which life is sustained, we focus on human actors acting" (Tronto 1993, 153). This view, which regards care at once as a moral disposition, a relational practice, a set of societal arrangements, and an ethical norm, criss-crosses the spheres of ethical and political, of discourse and practice. Thus, Tronto's political understanding of care ethics is intertwined with relational, processual understandings of social justice. Such understandings have been developed by a number of feminist theorists, alongside and in many cases in exchange with, Tronto's work. More specifically, Tronto's idea of care as standard and practice converges with Fraser's $(2007,29)$ understanding of social justice as, firstly, a substantive principle "by which we may evaluate social arrangements" and, secondly, a procedural standard "by which we may evaluate the democratic legitimacy of norms". According to this definition, social arrangements are "just if, and only if, they permit all the relevant social actors to participate as peers in social life", whereas norms are "legitimate if, and only if, they can command the assent of all 
concerned in fair and open processes of deliberation in which all can participate as peers" (Fraser 2007, 29).

Fraser coined the term participatory parity to denote such substantively and procedurally just arrangements. With that, she accorded the notion of voice central importance in her work, asserting that it makes "manifest the co-implication of democracy and justice", thereby supplying "just the sort of reflexivity that is needed in a globalising world" (Fraser 2007, 29). Fraser described injustice as a multi-layered, multidimensional phenomenon encompassing economic, cultural/legal, and political dimensions, since questions around who is able to make what kinds of justice claims against whom, and in what manner, are intertwined (cf. Fraser 1997; 2007; 2008). According to this model, social injustices occur, within the economic dimension, through a maldistribution of rights, opportunities, and resources. Misrecognitions unfold in the form of internal status hierarchies within the cultural and legal dimensions of social justice, while misrepresentations happen within the political dimension, for example through unfair and exclusionary rules and terms of engagement in public discourse and decision taking (cf. Hölscher 2014, 23-24). Fraser $(2007,2008)$ contended that justice was attainable only if a wide range of transformative discourses and practices worked together, from the global down to the local levels, to form virtuous cycles of increasing justice. Such transformative politics would be directed at bringing about more just distributions of rights, opportunities and resources, as well as an increasing recognition of difference, and of the legitimacy of differential needs and claims. And, they would be directed at an increasingly fair political representation within and across different polities, including a framing of membership in such polities as would afford all those affected by particular political decisions the opportunity to participate as equals in making them.

In short, Tronto's $(1993,154)$ contention that good care "requires ... a democratic and open opportunity for discussion, and more equal access to power" corresponds well with Fraser's ideal of participatory parity. But, what does good care actually entail? According to Fisher and Tronto (cited in Tronto 1993, 103), care is inclusive of "everything that we do to maintain, continue and repair our 'world' so that we can live in it as well as possible". To achieve its ends, care requires firstly that particular needs for care are recognised. It requires, secondly, that someone takes the responsibility to ensure that these needs are met in particular ways. Thirdly, there will be a direct, competent engagement with the recipients of care, including the physical work required to provide the care. Fourthly, care recipients must be enabled to respond with a view to indicating to what extent their needs have actually been met. Finally, over time, such "habits and patterns of care emerge" as are required for "trust and solidarity" to develop (Zembylas, Bozalek and Shefer 2014, 5-6; cf. Tronto 2013). 
Tronto also considered institutional requirements of good care and conditions that might place good care in jeopardy, noting that many institutions encourage a framing of vulnerabilities and concomitant needs for care as "misfortune" (Tronto 2010, 163) rather than as integral to human existence. One corollary of such framing is a tendency to interpret people's apparent dependency as inadequacy and, consequently, a tendency to disregard the experiences and judgements of care receivers. It is for such reasons that Tronto $(2013,33)$ stressed the importance of exploring how best "equality of voice" could be attained under conditions of inequality. Importantly, with "equality of voice" Tronto does not imply "customer satisfaction", warning instead against institutional framings of care as a commodity, rather than a process. Indeed, she observed that "any ... institution that presumes that needs are fixed is likely to be mistaken and to inflict harm in trying to meet such needs" (Tronto 2010, 164). Tronto (2010, 165) also cautioned against narrowing conceptions of care down to "care giving, rather than understanding the full process of care, which includes attentiveness to needs and the allocation of responsibility". This is because such a fragmented view of care provides " "passes' out of [caring] responsibilities" (Tronto 2013, 33; brackets added) for those who are removed from, yet responsible for shaping, the contexts in which caring practices unfold. Related to the issue of "passes" are several additional warning signs, one of which is that frequently, "care givers see organisational requirements as hindrances to, rather than support for, care" (Tronto 2010, $165)$ :

"Frequently, institutions cut budgets by cutting direct care workers, not managers. Care givers frequently complain that they have inadequate resources for their tasks at hand. When care givers ... [say] that they care despite the pressures and requirements of the organisation ... [and] when ... managerial rules ... come into conflict with the provision of care, it is time to rethink them." (Tronto 2010, 165-166).

The dynamic relationship between caring contexts and the broader, socio-economic and political contexts within which they are embedded, are the concern of the following section.

\section{NEOLIBERALISM AND THE INTERNAL CONTRADICTIONS OF HIGHER EDUCATION IN SOUTH AFRICA}

Caring contexts have been affected deeply by global changes in how capitalism functions developments which have accelerated greatly from the early 1970s onwards. These changes are denoted by the term neoliberalism, which signifies a global shift in power balances in favour of corporate capital accumulation strategies. The changes are most tangible in the increasing constraints on states' ability to serve as regulative, ameliorative and redistributive agencies 
(Sewpaul and Hölscher 2004). Worldwide, governments have been forced to curtail public spending - particularly in the fields of education, health, and welfare (Bauman 1998, Sayers 2015). As shown below, South African higher education is no exception to the trend. Both Fraser $(2012,2016)$ and Tronto (2013) considered this dynamic with reference to Karl Polanyi's The Great Transformation (Polanyi 2001 [1944]).

Fraser $(2012,4)$ described the current conjuncture as a global crisis of unprecedented intricacy and brutality, singling out the ecological, the financial, and "a strand pertaining to social reproduction" as particularly salient. These three crisis nodes are interlinked; for the purpose of this article however, I focus on social reproduction. This latter crisis is discernible in the "growing strain, under neoliberalism, on ... the human capacities available to create and maintain social bonds" (Fraser 2012, 4). According to her adaptation of Polanyi's work, its root causes lie in capitalism's tendency to "commodify" (that is, to turn into profit-making, purchasable, and sellable goods) all those aspects of human existence which, for reasons of their internal logic cannot, and for the market economy to function must not, be commodified. These aspects include "the work of socialising the young, building communities, of reproducing the shared meanings, affective dispositions and horizons of value that underpin social cooperation" (Fraser 2012, 4). As such, they entail the fields of education, health and welfare. Neoliberalism also has intensely gendered effects (cf. Fraser 2012, 2016), which include, but are by no means limited to, a commodification of gender relations generally and sexual relations more specifically. Section IV traces some of the ways in which these dynamics entrapped this study's participants in contemporary regimes of injustice.

The dynamic of this crisis becomes apparent when considering capitalism's inherent orientation towards profit. This orientation means not only that capitalists - and organisations structured around capitalist principles - are focused on producing and trading goods as their core purpose. It means also that they do so with a constant view to reducing and externalising input and production costs, to increasing returns, while perpetually looking out for new, and striving to expand existing, markets. As global power balances have shifted in favour of corporate capital, this orientation has "colonised" - that is progressively reframed, reinterpreted, and re-organised - spheres of life that had previously been organised according to non-capitalist principles (cf. Bauman 1998; 2004; Marcuse, cited in Tronto 2013). Over the past decades therefore, there has been a cumulative push to maximise the efficiency of labour, land, and money; to employ morality and ethics in the interest of profit; and to re-organise matters of pubic good - such as education, health and welfare - along the logic of markets.

The problem is that a market logic may be applied, to some extent, to some aspects of social and cultural life (Tronto 2013), yet these spheres are constituted by so much more than 
what can be quantified and commodified: consider for example affect, relationships and the meaning-making processes that occur within and between humans and their environments, and which can be valued only to the extent that they are not treated as goods, apt to be produced, traded, used, and discarded. To disregard those aspects of human existence that exceed and evade the market logic, disturbs, and will ultimately destroy, "the sociocultural processes that supply the solidarity relations, affective dispositions and value horizons that underpin social cooperation, while also furnishing the appropriately socialised and skilled human beings who constitute "labour'" (Fraser 2012,8). The outcomes of this dynamic can be observed globally in growing levels of exploitation and immiseration of increasing numbers of people, as previously self-sufficient ways of life are substituted by ones that fit into global, marketmediated modes of production and consumption (Bauman 2004; Sayers 2015).

In Caring Democracy, Tronto (2013) traced how neoliberalism has affected public attitudes and ways of organising care. Referring to the underlying ideology as market fundamentalism - that is "the view that markets are sufficient to allocate everything, including caring responsibilities" - Tronto (2013, 115) demonstrated neoliberalism's internal contradictions with reference, among others, to the field of education. Besides noting a number of respects in which a "free market" is incompatible with important aspects of care, Tronto (2013, 115-116) contended that market thinking "obscures structural inequalities" between differently positioned providers and receivers of care. She stressed that especially in claiming that "free markets" allowed people to "meet their own caring needs" while the needs of "the needy" could be addressed through charitable giving (Tronto 2013, 117-118), neoliberalists disregard all signs supporting "a relational, conception of human nature" (Tronto 2013, 121). Instead, embracing an "atomistic" (Tronto 2013, 121) worldview, free marketeers then proceed to make a whole string of other false assumptions, with profound effects on the management and provision of education, including higher education.

Once concerns about structural differences between the field of education and the market have been side-lined and the view has been mainstreamed that instead, market fundamentalism is accepted as an appropriate frame for thinking about education, the overall orientation of educational institutions can be re-directed towards cutting costs and increasing profits. A number of problems follow: education comes to be regarded as a tangible, measurable, tradable good, and managerial interventions are directed towards increasing efficiency in its production and sale. With "human resources" being key factors in such equations, this means attracting the largest possible number of students and ensuring that the price paid for their education is at as high as possible, considering the competition from other service providers. It also means employing a minimal number of educators at as limited a cost as possible in the face of existing 
labour market competition. This labour force will be required to deliver the institution's educational product with maximum efficiency, that is, to produce a maximum number of graduates in minimal time, while drawing on the least possible amount of resources.

Vivienne Bozalek's and Chrissie Boughey's (2012) critical review of higher education policies illuminates these dynamics within the context of public education in post-apartheid South Africa (cf. Badat 2016; Mbembe 2016). Bozalek and Boughey (2012) contended that there was a fundamental contradiction at the root of the continuing, deep inequities afflicting South African higher education. On the one hand, there was the need to promote equity following on centuries of colonial and apartheid rule, whilst on the other hand, the task was to contribute to South Africa's re-integration into "a rapidly globalising economy" (Wolpe, in Bozalek and Boughey 2012, 692). This contradiction was already discernible in the tensions between the 1997 White Paper on Higher Education and the 1998 Growth, Employment and Redistribution Programme: the former proposed "increased access and the massification of higher education at the same time as it called for the development of a knowledge economy", able to respond "to globalisation and labour market needs" (Bozalek and Boughey 2012, 692693). Yet in line with neoliberal orthodoxies, the latter policy directive resulted in "budget reprioritisation, rather than budgetary increase" becoming the South African government's “main strategy in addressing equity" (Fataar, in Bozalek and Boughey 2012, 693).

This initial contradiction was never overcome. Instead the range of policy interventions that followed may be interpreted instead as efforts to ameliorate its effects (Bozalek and Boughey 2012; Badat 2016; Mbembe 2016). A string of interventions, ranging from macro level policies down to the micro levels of individual support, targeted increasing "academic output" and redressing historical injustices in access to higher education. Still, the share of South Africa's gross domestic product allocated to higher education was boosted only marginally. In its place, most institutions of higher learning raised study fees and introduced a number of managerial tools to measure, entice, and enforce both productivity and redress in the absence of any concomitant increase in resources (Bozalek and Boughey 2012; Badat 2016). The outcome, arguably, was a deepening, widening and sharpening of the original paradox and ultimately, the commodification of South African higher education; that is, it "colonisation" by free market terms and conditions (Bozalek and Boughey 2012; Mbembe 2016).

These deepening contradictions can be flagged, in numerical terms, with reference to the leg of the study on participatory parity in which my colleague and I were involved, that is, the discipline of social work at a merged, urban university (Bozalek 2014; see introduction above). Over a decade, I witnessed significant changes in the discipline's teaching and learning context. According to records collected between August 2007 and July 2017, the discipline was made 
up, in 2007, of twelve full-time lecturing staff, with one vacant position. At the point of writing this article in 2017, the teaching body had been reduced by 25 per cent to nine staff members, with four unfilled posts. In the same time period, the number of undergraduate students had grown from below 400 to over 800 . There were also changes in the level of seniority among staff: in August 2007 eight of twelve had PhDs, seven of whom held senior academic positions. Yet in July 2017, only two colleagues had PhDs, and there were no senior academics in the discipline. The growing staffing shortfall had been made up to some extent by a myriad of fixed term appointments; yet it must be assumed that over the preceding ten years, the human resource cost attached to the running of the social work programme had decreased considerably; this in spite of the simultaneous doubling of student numbers.

Noteworthy therefore are a number of developments in the discipline's gender, "race", and class profiles. In August 2007, all lecturing staff were female. By July 2017, this had changed little, with only one male having joined the team. Also in August 2007, 25 per cent of staff were categorised as Black. By July 2017, this percentage had increased significantly, with eight out of nine staff members thus categorised. At the same time, the share of single-income households among lecturers had grown from a quarter in August 2007 to seven out of nine in July 2017. Among students, the percentage of males increased from 13 per cent in 2007 to 25 per cent in 2017. In the same period, the percentage of students listed as Black increased from 89 to 99 per cent. And in 2017, 82 per cent of all students relied on third party funding (including NSFAS and a limited number of other loans and bursaries) for their upkeep, as opposed to 53 per cent in 2007. Finally, the percentage of students from the three lowest high school quintiles more than doubled from 22 to 53 per cent. Together, these figures suggest that in the course of just ten years, the resources required to ensure the well-being and academic development of both social work students and staff at the institution concerned may have grown considerably. The implications of these contextual changes for the living and learning of students and staff of the discipline are discussed below.

\section{NEOLIBERALISM AND THE (IM)POSSIBILITIES OF CARE: STUDENT AND LECTURER EXPERIENCES}

Following the preceding two sections' arguments about the marketization of higher education in South Africa and the ways in which any maldistribution of resources is interlinked in complex ways with the injustices of misrecognition, misrepresentation and misframing, it is perhaps unsurprising that by 2016 , Badat $(2016,4)$ spoke of a diminished "overall student experience" in institutional contexts where the voices of those at whom redress was ostensibly directed were insufficiently heard, and the experiences, needs and aspirations of a changed 
student population inadequately cared for. Precisely this is illustrated by the discussions of the 25 final year social work students, who participated in the study on participatory parity in South African higher education. How they articulated their concerns, what kinds of solutions they proposed, and the ways in which these were connected with my own perceptions and experiences, are the subject of this section.

Participants self-selected in that they chose to be part of the study from a number of available options in their Level 4 Research Module. There were no incentives to participate in this project, nor were any negative repercussions attached to pursuing alternative research interests. In keeping with the module requirements, participants developed research proposals in groups of three to five, thereby positioning themselves both as researchers and research participants. Within the framework of the larger project, they developed their own research interests, aim and objectives. As part of their data collection, students produced artwork on, and held discussions around, their life stories and the range of factors that both enabled and hindered their living and learning at the institutions at which they were based (Chambers 2006; Bozalek 2011, 2013; Wang 2006). Thereafter, each wrote an individual research report. This article is based on the students' original data.

\section{Money, sex, and sex for money}

In the nine group sessions, held in August 2015, the devastating and demoralising effects of being short of money was a dominant theme. Luthando's ${ }^{2}$ experience of how her desire for education impacted family relations was typical:

"[When I came to the university,] I only had money to pay my registration ... [There were family disputes about] who is responsible for paying the child .... Parents would argue and as children, we will hear them .... All that is so emotionally draining and causes stress .... I wish I could learn that money is not everything." (Brackets added).

Once admitted to university, basic sustenance became another challenge. For example, Mongezi claimed that the management of student access to food curtailed her access to nutrition:

"One of the things that hinder my learning ... is the café; it's very expensive .... We have ... people ... who ... sell chips, fat cakes .... As you can see, the relationship between the student [on my picture] and those people (pointing) is very good for us ... who ... don't have enough money .... [But sometimes] you don't see [the sellers] showing up, [and] they will say that, 'the university are kicking us out' .... It's difficult to be part of this ... university." (Brackets added).

In addition, shortages pertaining to accommodation, teaching and learning infrastructure, and 
staffing, impacted students' learning experiences negatively. This illustrated the ways in which the dominance of the profit motif, overarching demands to reduce input costs, and the fact that in South Africa budgetary increases haven't kept pace with increased student access to higher learning, can affect the day-to-day living and learning of students. Topics discussed repeatedly and across all nine sessions included: overcrowding of residences and classrooms; inadequate numbers of text books and computers; broken infrastructure ranging from water supply to lecture theatre equipment; and long queues outside student services offices. All these challenges were raised, just over a month later, in the context of the 2015/2016 student uprisings in South African public universities (cf. Badat 2016; Mbembe 2016). Moreover, in students' experiences of scarcity, the issue of education's commodification featured prominently in that seemingly all aspects of their participation in the learning process had to be paid for - with money they often did not have. For instance, after Londeka related how at times she missed assignment submission dates because she was unable to print her work, Asande complained that, "we pay for student cards, we pay for academic records, [and] we pay for [printing] credits" (brackets added). She concluded:

"The pressure starts in us now to date sugar daddies so that we can get the money .... So it's like the survival of the fittest."

Indeed, the central importance of money combined with its simultaneous scarcity in all aspects of living and learning at the university was identified by several participants as a key driver behind poor female students being subjected to sexual exploitation. As Patience put it, "It goes back to being poor .... Not having sufficient money to study makes me vulnerable".

One particularly stark illustration of Patience's contention was the allegation, articulated by several of the study's participants, that persons close to the student representative council (SRC) and the department of student housing were soliciting bribes and sexual favours in exchange for access to university residences. Mbali, having attributed a previous psychological breakdown to her experience of selling sex for money, indicated that she would do it again:

"Corruption is a chain .... These people in management; this one knows this one, this one knows that one and that one knows that one, so ... I [might] say something but ... I'm just a student. Nobody knows me and is willing to listen to me .... So I might be like, 'Okay fine, I won't sleep with him', but at the end of the day, I'm the one who is going to suffer because ... I'm not going to get the place to stay .... If we are not going to sleep with them where are we gonna get help? ... Fine, I might go to a lecturer that I know ... but at the end of the day, that somebody will ... refer me back to the counsellor who will say, 'Ngikutshelile ukuthi', 'Sleep with me' .... It's like ... justice will never be served anywhere we go." (Brackets added). 
Yet even where less glaring, voicelessness and powerlessness were still a dominant student concern. For example, Sethu recounted the indignity of having to wait for hours in long queues to present pressing and troubling issues to what, to most participants, seemed unsympathetic officials, often missing lectures in the process. This led Luthando to wonder if administrative staff might be too few, inadequately skilled, or both. Time and again, participants acknowledged the help they had received from certain individuals in the system, including from members of the SRC, as well as the lengths to which some of the latter went to represent them to university structures in times of need. Yet in the face of experiences such as sexual exploitation from some of those on whose help they depended, participants expressed the view that the university in general, and the institution of the SRC in particular, had lost legitimacy and could not be trusted to recognise, or represent, their concerns. Again, this was linked to the question of commodification, as expressed aptly by Mbali:

"When it comes to the voting times where you have to sell yourself to the public, I won't say, 'To get something you will have to sleep with me'. I'm going to sell myself at best, for you to vote for me, in such a way that you're gonna buy me. But at the end of the day when I'm in power, I know I'm in power."

Through these kinds of contribution the students rendered tangible Fraser's $(2012,4)$ abovecited contention that capitalism's tendency to commodify aspects of human existence that cannot and should not be commodified, undermined, inter alia, "the work of ... building communities [and] of reproducing the ... affective dispositions and [value] horizons ... that underpin social cooperation" (brackets added). More specifically, they exemplified how such commodification might have contributed to an atomistic view of students' struggles to live and learn at the university, thereby feeding an institutionalised disregard of vulnerability as structural (cf. Tronto 2010, 2013). It appears that in the process, poor students' vulnerability to exploitation may have been enhanced, rather than historical inequities being addressed.

\section{Time, fear, and times of fear}

Besides Mbali (above), several other students bemoaned that when sharing the challenges they faced with their lecturers - including me - they might be listened to sympathetically but ultimately, they would be referred onwards to other departments: student counselling, housing, finance, or the SRC. This is a far cry from Tronto's understanding of care, from Fraser's notion of transformative politics, and from the idealised forms of social work taught in the classroom. After all, social work defines itself by its commitment to "social cohesion, and the empowerment and liberation of people" (IFSW/IASSW 2014), and the profession's ethics 
guide social workers among others, to "challenge unjust policies and practices" (IFSW/IASSW 2004). What is it about the prevailing conditions that contributes to such incongruence between what we claim to be teaching and how we conduct ourselves as teachers? By focusing attention in particular ways, Fraser's and Tronto's ideas concerning the care/justice interface and arguments about how this interface is affected by the crisis of capitalism can assist in discerning available openings towards transformative relationships and practices. In my own reflections, the two authors' respective works have drawn my attention to three episodes in my life as a lecturer, two of which preceded the study, while the third occurred immediately after the group sessions quoted here. Firstly, there is a diary entry of mine dated March 2009, which reads:

"My workload has increased further, leaving me almost no time to ... respond to the needs [of others] .... Even recognising people ... and responding to them ... takes time. And time I do not have ... I am trapped in ... [the] structural straightjacket ... [of a] system ... which ... is geared increasingly towards filling the last spaces of academic freedom ... with demands for student output and administrative responsibilities. Moral and political action must come out of a person's recreational time and personal space, which, too, is increasingly occupied by economic demands." (Brackets added).

The second incident pertains to a class discussion held in 2013, against the background of one of the many student protests at the university that preceded the 2015/2016 student uprisings. We were talking about the use of burning and destruction of university property as a means of protest, which I considered to be a dangerous and counter-productive strategy. As I stated my points, I felt a surge of hostility, in response to which I asked with some exasperation, "Well, what do you want?!" After the class had fallen silent, a student in the back of the lecture theatre stood up and said slowly, "We want you to be with us". That was when I realised that I was scared; scared of acting on my feelings of solidarity with students at a time of heightened conflict. Could it be construed as "insubordination", or as "bringing the university into disrepute"? Would it place my livelihood in danger?

The issues of fear and time re-appeared in the weeks following data collection for this study. I was particularly unsettled by the students' discussions around sexual exploitation. Patience had suggested that after the completion of the research, we should present the study's findings to the public so that "everyone in the university" could "hear the voice of the students". My colleague and I considered the possible repercussions of displaying the students' artefacts and findings while they were still enrolled at the university, as well as the option of representing their voices after they left. We were concerned that any public display of such information as we now possessed might either cause us to be accused of bringing certain persons and parts of the institution into disrepute or place our students' and our own safety at risk. At the same time, 
we did not want to facilitate a public display of the students' voices and then censor some of their most pressing concerns. We also thought about making use of the university's available avenues for reporting suspected corruption but, like our students, did not fully trust them. What if the confidentiality of these avenues were violated? Then, we considered the possible repercussions of not reporting the students' allegations. Were we not legally obliged to report? Finally, we were worried about how much time we had to spare on this matter. How would reporting affect our obligations to publish, finish our $\mathrm{PhDs}$, teach, mark, and see to the administration of the discipline? Would we have the emotional energy to see this through? In the end, we could not make up our minds and as time passed, we spoke less and less about the issue, while I took meek solace in the idea that, "these kinds of things happen everywhere".

In Section II, I referred to Tronto's (2013) contention that good care requires sufficient time for the formation of such habit and patterns of trust and solidarity to occur as might render education generative of social justice (cf. Zembylas, Bozalek and Shefer 2014). I also cited Tronto's $(2010,165)$ assertion that frequently, "care givers see organisational requirements as hindrances to, rather than support for, care". What emerges from my reflections on my own role and difficulties in responding to students' expressed needs for care, is that in an institutional context where that which emerges between people - including what they share, learn and write about - becomes fixed, priced and traded, time itself becomes a production factor and as such, prone to be rationed and rendered scarce. Under such conditions, trust will struggle to emerge, and relations and practices of solidarity between care givers and care receivers, between lecturers and students, will be difficult to grow. Citing Baumol, Tronto $(2013,8)$ refers to this as care's "cost disease", a term which denotes that "an important aspect of care is simply spending time" engaging, listening, observing and responding, and that beyond a certain threshold therefore, "no greater ... efficiencies can be achieved" (Tronto 1993, 121). Treating higher learning as a market place may thus deprive lecturers of important means for engaging competently with students. It may simultaneously block key avenues for making their own voices heard by those who are removed from, yet responsible for shaping the contexts in which pedagogical practices unfold. This then undermines their ability to contribute to meeting students' educational needs - or any other needs arising for differently positioned participants in educational processes and contexts. Instead, educational practices risk mirroring and reproducing, rather than resisting and developing alternatives to, the contextual injustices within which they are embedded.

\section{Caring for justice}

So far, I described the contextual conditions under which the university has been misframed as 
a market place, where maldistribution, misrecognition and misrepresentation characterise much of how poor students and lecturers relate, and where money and time have been rendered so scarce as to entangle them in prevailing dynamics of injustice. Are there any openings for change? Can such vicious cycles of injustice be turned into virtuous cycles in which alternatives are generated, explored, and shared? Based on the students' contributions to the study, I contend that a key to inverting the dynamic described so far lies in how we think about care, and try to contribute towards the expansion of spaces in which good care becomes possible. As did several other participants, Sisanda pointed out that during the group process, she experienced an "affective solidarity" (Hemmings 2012) that she found empowering:

"To talk about things that are not going well, about things that I have never talked about ... was very inspirational .... To see that you're not the only one who has ... bad experiences, and also [to hear about] other good experiences ... showed me that we are very strong." (Brackets added).

Besides Patience's suggestions (above), my question of what could be done to take the experiences of the study forward generated a number of responses, including Luthando's suggestion to hold "monthly talking sessions" and Mongezi's suggestion that the social work student association should engage in ongoing "dialogues" with a view to generating "some ... ideas in how to deal with those things". Patience concluded the discussion by stating that, "If we were to work as a team in this university and not be about making money, I think that such things can work".

So not only did the design of the study "open opportunity for discussion" and, for the period of its duration, allow for "more equal access to power" (Tronto 1993, 154), it also enabled participants to develop a standard for what they wanted their educational encounters to look like going forward. Having experienced glimpses into what participatory parity might be like, students suggested that the solution to a range of their problems lay in demanding more opportunities to relate on a par with, and to have their voices heard by, a diverse range of actors in the university. In this context, students reiterated their view that the commodification of education, as signified by the scarcity of money in their lives, was a hindrance that had to be addressed. Implicit in their suggestions was that attitudinal changes concerning money needed both to precede and happen alongside political action for social justice.

In the students' experience, existing structures and processes of representation did not go far enough in furthering the ends of care and justice; instead they seemed integral to some of the violations discussed. While the seriousness of these violations calls for responses on a number of levels, my focus here is on their implications for the lecturer-student interface. In caring for justice, pedagogical practices should be oriented towards understanding and 
addressing different forms of voicelessness experienced by those who find it difficult in the current dispensation to have their claims for justice heard. They would seek to contribute to students feeling safe to express their views in public, and to have them taken seriously and responded to by those with the relative power to do so. And they would seek to identify and create enablements for those who are affected most by prevailing injustices, to participate in addressing them. To act in solidarity with their students, however, lecturers would have to engage with their own experiences of lacking care, apply the strategies suggested by the students in their own spheres, and re-articulate their own demands for voice. They would have to re-assert their right to engage as equals with those who those who are removed from, yet responsible for shaping, the contexts in which their teaching and writing, that is their own academic development, must unfold.

\section{CONCLUSION}

This article opened with Tronto's (2014a, 22) contention that "care ... profoundly stands against one of the sharpest of the current masters' tools: neoliberalism". The student contributions and reflections presented thereafter suggest that indeed, to care is in itself a subversive practice, apt to substitute some of the key conditions and processes that lie at the root of contemporary injustices in South African higher education. In particular, it has been possible to show that Fraser's and Tronto's respective works on justice and care, on the crisis of capitalism, and on its effects on care, have some inherent, critically reflexive components. Viewing our pedagogical practices through these lenses thus can sensitise participants in South African higher education to our own entanglement in structures and processes of injustice, thereby affecting what we think and talk about. In this way, their works impact what we might choose and feel able to act upon, and so assist in discerning, utilising and expanding available openings for more caring and transformative practices, even and especially under conditions of neoliberalism.

\section{NOTES}

1. Ethical clearance for this study was received both from the university where the lead researcher was based, and from the local university where the leg of the study reported on in this article was implemented.

2. Note that all participants' names have been changed.

\section{REFERENCES}

Badat, S. 2016. Deciphering the meanings, and explaining the South African higher education student protests of 2015-16. South African History Online. http://www.sahistory.org.za/archive/ deciphering-meanings-and-explaining-south-african-higher-education-student-protests-2015-16 
(Accessed March 2017).

Bauman, Z. 1998. Globalisation: The human consequences. Cambridge: Polity Press.

Bauman, Z. 2004. Wasted lives: Modernity and its outcasts. Cambridge, Oxford and Malden: Polity Press.

Bozalek, V. G. 2011. Acknowledging privilege through encounters with difference: Participatory learning and action techniques for decolonizing methodologies in Southern contexts. International Journal of Social Research Methodology 4(6): 465-480.

Bozalek, V. G. 2012. Interview with Nancy Fraser. Social Work Practitioner/Researcher 24(1): 136151.

Bozalek, V. G. 2013. Participatory learning and action (PLA) techniques for community work. In Participation in community work: International perspectives, ed. A. K. Larsen, V. Sewpaul and G. O. Hole, 57-71. London: Routledge,

Bozalek, V. 2014. Detailed proposal for the project, participatory parity and transformative pedagogies for qualitative outcomes in higher education (NRF Grant No. 90384). University of the Western Cape: Directorate of Teaching and Learning.

Bozalek, V. G. and C. Boughey. 2012. (Mis)framing higher education in South Africa. Social Policy \& Administration 46(6): 688-703.

Chambers, R. 2006. Notes for participants in PRA-PLA Familiarisation Workshops in 2006. Institute of Development Studies. University of Sussex. http://www.ids.ac.uk/ids/particip/ (Accessed February 2017).

Fraser, N. 1997. Justice interruptus: Critical reflections on the "postsocialist" condition. London and New York: Routledge.

Fraser, N. 2007. Re-framing justice in a globalising world. In (Mis)recognition, social inequality and social justice: Nancy Fraser and Pierre Bourdieu, ed. T. Lovell, 17-35. Abington and New York: Routledge.

Fraser, N. 2008. Scales of justice: Reimagining political space in a globalising world. Cambridge: Polity Press.

Fraser, N. 2012. Can societies be commodities all the way down? Polanyan reflections on capitalist crisis. HAL ARCHIVES-OUVERTES. https://halshs.archives-ouvertes.fr/halshs-00725060 (Accessed December 2016).

Fraser, N. 2016. Contradictions of capital and care. New Left Review July-August 2016: 99-117.

Hemmings, C. 2012. Affective solidarity: Feminist reflexivity and political transformation. Feminist Theory 13(2): 147-161.

Hölscher, D. 2014. Considering Nancy Fraser's notion of social justice for social work: Reflections on misframing and the lives of refugees in South Africa. Ethics \& Social Welfare 8(1): 20-38.

IFSW/IASSA see International Federation of Social Workers.

International Federation of Social Workers/International Association of Schools of Social Work (IFSW/IASSW). 2014. Global definition of social work. http://ifsw.org/get-involved/globaldefinition-of-social-work/ (Accessed July 2015).

International Federation of Social Workers/International Association of Schools of Social Work (IFSW/IASSW). 2004. Ethics in social work: Statement of principles. http://ifsw.org/resources/ definition-of-social-work/ (Accessed May 2011).

Mbembe, A. J. 2016. Decolonizing the university: New directions. Arts and Humanities in Higher Education 15(1): 29-45.

Polanyi. 2001 [1944]. The great transformation. Boston: Beacon.

Sayers, A. 2015. Why we can't afford the rich. Revised ed. Bristol: Policy Press.

Sewpaul, V. and D. Hölscher. 2004. Social work in times of neoliberalism: A postmodern discourse. Pretoria: Van Schaik. 
Tronto, J. C. 1993. Moral boundaries: A political argument for an ethic of care. New York and London: Routledge.

Tronto, J. C. 2010. Creating caring institutions: Politics, plurality and purpose. Ethics \& Social Welfare 4(2): $158-171$.

Tronto, J. C. 2013. Caring democracy: Markets, equality, and justice. New York: New York University Press.

Tronto, J. C. 2014a. Moral boundaries after 20 years: From limits to possibilities. In The significance of Joan Tronto's argument for political theory, professional ethics and care as practice, ed. G. Olthuis, H. Kohlen and J. Heier. Peeters: Ethics of Care 3(2014): 9-26.

Tronto, J. C. 2014b. Ethics of care: Present and new directions. In The significance of Joan Tronto's argument for political theory, professional ethics and care as practice, ed. G. Olthuis, H. Kohlen and J. Heier. Peeters: Ethics of Care 3(2014): 215-227.

Wang, C. C. 2006. Youth participation in photovoice as a strategy for community change. Journal of Community Practice 14(1-2): 147-161.

Zembylas, M., V. G. Bozalek and T. Shefer. 2014. Tronto's notion of privileged irresponsibility and the reconceptualisation of care: Implications for critical pedagogies of emotion in higher education. Gender and Education, published online May 2014. DOI: 10.1080/09540253.2014.901718. 